\title{
Case Based Reasoning dalam Menentukan Titik Indikasi Gangguan Jin untuk Ruqyah Menggunakan Silimilaritas Braun-blanquet
}

\author{
Wahyu Trihadi Saputra ${ }^{\# 1}$, Tursina ${ }^{\# 2}$, Yulianti ${ }^{\# 3}$ \\ \#Program Studi Informatika Universitas Tanjungpura \\ Jl. Prof. Dr. H. Hadari Nawawi, Pontianak 78124 \\ ${ }^{1}$ wahyutesaputra@gmail.com \\ ${ }^{2}$ tursina@informatika.untan.ac.id \\ ${ }^{3}$ Y_suanda@gmail.com
}

\begin{abstract}
Abstrak-Ruqyah syar'iyyah adalah bacaan yang terdiri dari ayat-ayat Al-Qur`an dan hadits-hadits Rasulullah shallallaahu 'alaihi wa sallam yang shahih, untuk memohon kesembuhan kepada Allah dari gangguan yang ada. Tata cara ruqyah yaitu meletakkan tangan pada bagian badan yang dirasakan sakit kemudian mengucapkan bacaan ruqyah. Seiring dengan bertambahnya pengalaman dalam melakukan ruqyah, baik ruqyah diri sendiri maupun orang lain. Praktisi ruqyah dapat memanfaatkan pengalaman dalam melakukan ruqyah untuk membantu menentukan titik indikasi gangguan jin pada tubuh pasien. Gejala yang dirasakan dibagi menjadi dua jenis, yaitu gejala fisik dan gejala psikis. Pengalaman tersebut dikumpulkan menjadi basis kasus, sehingga sangat memungkinkan untuk dibuat sistem penalaran berbasis kasus atau Case Based Reasoning (CBR). Penelitian ini bertujuan untuk membangun sistem CBR yang dapat menentukan titik indikasi gangguan jin pada tubuh manusia. Proses CBR melalui 4 tahap yaitu Retrieve, Reuse, Revise dan Retain. Hal yang terpenting dalam CBR adalah menentukan nilai kemiripan atau similaritas antara kasus-kasus yang tersimpan di basis kasus dengan kasus baru yang akan dicari solusinya. Perhitungan similaritas kasus pada penelitian ini dilakukan dengan metode Braun-blanquet (B-b). Sistem pada penelitian ini dibatasi hanya pada kasus bagian kepala. Berdasarkan hasil pengujian validasi membandingkan hasil diagnosis pakar dengan hasil diagnosis sistem terhadap 65 data kasus, terdapat 53 kasus yang sesuai. Dengan demikian tingkat keberhasilan sistem adalah $81,54 \%$.
\end{abstract}

Kata Kunci-Case Based Reasoning, ruqyah, similaritas, braunblanquet

\section{PENDAHULUAN}

Ruqyah merupakan cara pengobatan dan terapi nabawi yang seharusnya menjadi pilihan utama bagi setiap muslim dalam mengobati penyakit, bukan sebagai alternatif sampingan. Selain itu, ruqyah juga merupakan senjata ampuh untuk melawan dan mengusir setan dan segala keburukan yang ditimbulkannya. Sebagai ikhtiar penyembuhan, ruqyah merupakan kebutuhan sangat urgen yang tidak boleh diremehkan [1].

Termasuk dalam tata cara ruqyah adalah meletakkan tangan pada bagian badan yang dirasakan sakit kemudian mengucapkan bacaan ruqyah [1]. Berdasarkan pengalaman praktisi ruqyah, sering ditemukan bahwa gangguan jin dapat menyebabkan korbannya terkena penyakit fisik yang dampaknya sangat berbahaya bagi kesehatan manusia. Ini semua terjadi karena kehendak Allah subhaanahu wa ta'aala pula. Berdasarkan pengalaman, titik indikasi area tubuh manusia yang diserang oleh jin dapat diketahui dari tandatanda dan dampak yang biasa ditimbulkannya [2].

Seiring dengan bertambahnya pengalaman dalam melakukan ruqyah, baik ruqyah diri sendiri maupun orang lain. Praktisi ruqyah dapat memanfaatkan pengalamannya tersebut untuk membantu menentukan titik indikasi gangguan jin pada tubuh pasien. Gejala yang dirasakan dibagi menjadi dua jenis, yaitu gejala fisik dan gejala psikis. Gejala yang dirasakan oleh pasien dan titik indikasi yang didapat akan disimpan dalam bentuk pengalaman yang dapat berguna untuk kasus atau pasien lain dalam membantu menentukan titik indiikasi gangguan jin pada dirinya. Pengalaman tersebut dikumpulkan menjadi basis kasus, sehingga sangat memungkinkan untuk dibuat sistem Case Based Reasoning (CBR) atau penalaran berbasis kasus. Sistem CBR dapat membantu menentukan titik indikasi gangguan jin untuk ruqyah. 
Case Based Reasoning (CBR) merupakan penalaran yang bertujuan untuk menyelesaikan permasalahan baru dengan cara mengadaptasi solusi-solusi yang terdapat pada kasuskasus sebelumnya yang mempunyai permasalahan yang mirip dengan kasus yang baru. Sumber pengetahuan utama sistem CBR adalah berdasarkan kasus-kasus yang telah ada atau yang telah tersimpan di dalam basis kasus [3]. Sumber data utama yang diperoleh sebagai penunjang dalam membangun CBR pada sistem ini adalah data kasus dari praktisi ruqyah. Sistem yang dibuat menggunakan fitur berupa gejala fisik dan psikis. Sistem pada penelitian ini dibatasi hanya pada kasus bagian kepala. Input dari sistem yang dibuat berbentuk biner yaitu 1 (ya) atau menyatakan ada gejala dan 0 (tidak) yang menyatakan tidak ada gejala. Perhitungan similaritas kasus menggunakan metode Braun-blanquet $(B-b)$ yang merupakan salah satu cara perhitungan similaritas untuk data biner.

Sistem yang dibangun berbasis web. Aplikasi berbasis web dapat diakses dari berbagai perangkat dengan syarat menggunakan web browser saja sudah dapat mengaksesnya [4].

\section{URAIAN PENELITIAN}

\section{A. Case Based Reasoning}

Case Based Reasoning (CBR) merupakan penalaran yang bertujuan untuk menyelesaikan permasalahan baru dengan cara mengadaptasi solusi-solusi yang terdapat pada kasuskasus sebelumnya yang mempunyai permasalahan yang mirip dengan kasus yang baru. Sumber pengetahuan utama sistem CBR adalah berdasarkan kasus-kasus yang telah ada atau yang telah tersimpan di dalam basis kasus [3].

CBR harus melakukan beberapa tahapan proses untuk menghasilkan solusi suatu masalah diantaranya adalah mencari kemiripan kasus baru dengan kasus yang tersimpan. Tahapan proses pada CBR dalam mencari nilai kemiripan dibutuhkan empat (4) tahap.

a) Retrieve (penelusuran) adalah menemukan kembali kasus yang sama atau yang paling mirip dengan kasus baru.

b) Reuse adalah menggunakan kembali informasi dan pengetahuan dari basis kasus untuk memecahkan masalah kasus baru.

c) Revise adalah merevisi atau memperbaiki solusi yang diusulkan.

d) Retain adalah menyimpan pengalaman untuk memecahkan masalah yang akan datang ke dalam basis kasus.

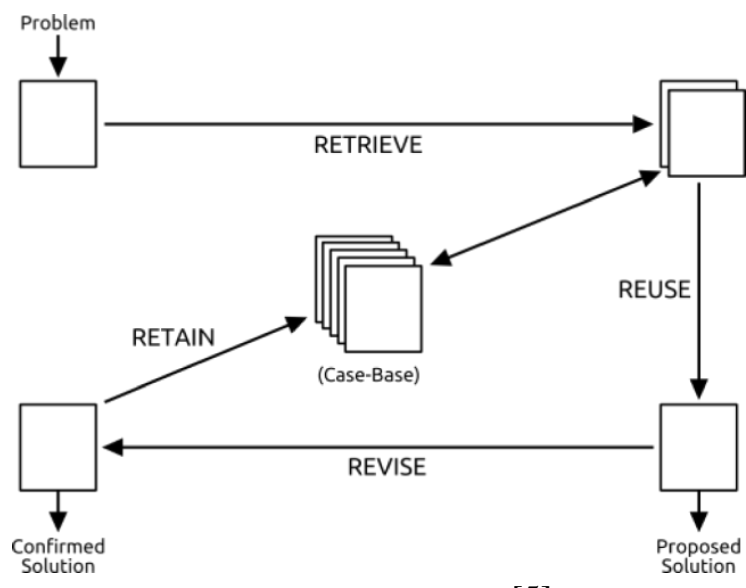

Gambar 1. Tahapan CBR. [5]

Berdasarkan tahapan yang ada dalam CBR, diperlukan dua langkah utama dalam menentukan solusi. (Tursina, 2012)

a) Membangun basis kasus, yang digunakan sebagai tempat penyimpanan.

b) Menentukan fungsi kemiripan (similarity), langkah ini digunakan untuk mengenali kesamaan atau kemiripan antara kasus-kasus yang tersimpan dalam basis kasus dengan kasus yang baru.

\section{B. Metode Braun-blanquet $(B-b)$}

Salah satu cara untuk menghitung similaritas dua objek yang bersifat biner adalah dengan menggunakan metode braun-blanquet. Formula yang digunakan braun-blanquet untuk menghitung similaritas antara dua objek $\mathrm{x}$ dan y adalah pada persamaan 2.1 berikut.

$$
\begin{aligned}
\text { Braun-Blanquet }(x \cdot y)= & \text { if }(a+b)>(a+c) \text { then } S:=a /(a+b) \\
& \text { else } S:=a /(a+c)
\end{aligned}
$$

Keterangan:

$\mathrm{x}$ : mewakili kasus lama

y: mewakili kasus baru

a: mewakili jumlah atribut biner, $x=1$ dan $y=1$

b: mewakili jumlah atribut biner, $x=1$ dan $y=0$

c: mewakili jumlah atribut biner, $\mathrm{x}=0$ dan $\mathrm{y}=1$

S: mewakili nilai similaritas

\section{Unified Modelling Language (UML)}

UML merupakan bahasa visual untuk pemodelan dan komunikasi mengenai sebuah sistem dengan menggunakan diagram dan teks-teks pendukung [6]. UML adalah metodologi untuk mengembangkan sistem OOP dan sekelompok tool untuk mendukung pengembangan sistem. UML adalah salah satu standar bahasa yang banyak digunakan di dunia industri untuk mendefinisikan requirement, membuat analisis dan desain, serta menggambarkan arsitektur dalam pemrograman berorientasi objek. 


\section{PERANCANGAN SISTEM}

\section{A. Diagram Alir Sistem}

Diagram alir sistem akan ditunjukkan pada Gambar 2.

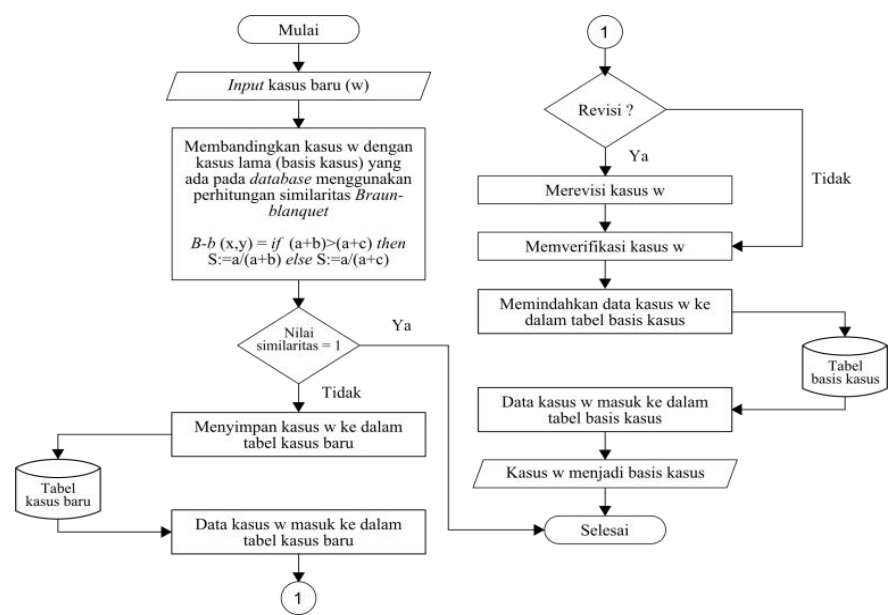

Gambar 2. Diagram alir sistem penentuan titik indikasi gangguan jin pada tubuh manusia.

Diagram alir sistem pada Gambar 3.3 dimulai dengan input kasus baru yang selanjutnya disebut dengan kasus w. Sistem melakukan perbandingan kasus $\mathrm{w}$ dengan kasus lama (basis kasus) yang tersimpan di dalam database. Proses perbandingan ini akan menghasilkan nilai similaritas yang dihitung dengan metode braun-blanquet. Jika nilai similaritas sama dengan 1, maka proses selesai. Jika nilai similaritas tidak sama dengan 1, maka kasus w akan disimpan ke dalam tabel kasus baru. Tabel kasus baru menyimpan seluruh data kasus baru yang telah dimasukkan ke dalam sistem yang mana data tersebut dapat diolah oleh admin. Admin dapat merevisi dan memverifikasi data kasus baru agar dapat menjadi basis kasus. Basis kasus akan digunakan sistem sebagai acuan solusi atas kasus baru lainnya.

\section{B. Fitur Gejala dan Titik Indikasi}

Tabel 1.

Keterangan fitur gejala pada penelitian.

\begin{tabular}{|l|l|}
\hline Fitur & \multicolumn{1}{|c|}{ Keterangan } \\
\hline F001 & Rambut Sering Rontok \\
\hline F002 & Sering Sakit Kepala \\
\hline F003 & Migrain \\
\hline F004 & Kepala terasa berat \\
\hline F005 & Mata terasa rabun, tapi terkadang terang \\
\hline Fitur & \multicolumn{1}{c|}{ Keterangan } \\
\hline F006 & Mata terasa mau copot/lepas \\
\hline F007 & Sering keluar air mata \\
\hline F008 & Juling \\
\hline F009 & Melotot \\
\hline F010 & Pandangan tajam \\
\hline F011 & Wajah sering terasa kebas \\
\hline F012 & Wajah kelihatan jelek atau tua \\
\hline F013 & Gatal di wajah \\
\hline F014 & Muncul bintik-bintik merah di wajah atau jerawat \\
\hline
\end{tabular}

Korespondensi : Wahyu Trihadi Saputra

\begin{tabular}{|l|l|}
\hline F015 & Kulit wajah berubah hitam \\
\hline F016 & Hidung sering mampet \\
\hline F017 & Hidung sinus \\
\hline F018 & Pilek menahun \\
\hline F019 & Hidung gatal \\
\hline F020 & Susah bicara \\
\hline F021 & Sering sakit gigi \\
\hline F022 & Gigi dan gusi ngilu \\
\hline P001 & Lupa (terutama rakaat shalat) \\
\hline P002 & Linglung \\
\hline P003 & Tidak fokus \\
\hline P004 & Sering mengantuk \\
\hline P005 & Susah tidur \\
\hline P006 & Susah dapat jodoh \\
\hline
\end{tabular}

Penjelasan Tabel 1 bahwa dari 2 jenis gejala yang ada (gejala fisik dan gejala psikis), terdapat 28 fitur yang digunakan dalam penelitian dengan rincian 22 fitur gejala fisik dan 6 fitur gejala psikis.

Tabel 2

Keterangan kode titik indikasi pada penelitian.

\begin{tabular}{|c|l|}
\hline Kode & Keterangan \\
\hline KP & Kepala \\
\hline KM & Kelopak Mata \\
\hline MW & Muka (wajah) \\
\hline HD & Hidung \\
\hline MT & Mulut \\
\hline
\end{tabular}

Penjelasan Tabel 2 bahwa sistem pada penelitian ini dibatasi hanya pada kasus bagian kepala yang mana terdapat 5 titik indikasi.

\section{Use Case Diagram}

Use case diagram sistem akan ditunjukkan pada Gambar 3. Pada Gambar 3 terdapat dua aktor, yaitu aktor pengguna dan aktor admin. Pengguna dapat mengakses menu konsultasi, informasi akidah Islam, informasi panduan ruqyah, informasi bantuan penggunaan aplikasi pada menu konsultasi, serta informasi tentang aplikasi. Sedangkan admin dapat melakukan manajemen data basis kasus, yaitu menambah, mengedit, maupun menghapus.

Admin juga dapat memanajemen data kasus baru, yaitu memverifikasi, merevisi, maupun menghapus. Data fitur dapat admin tampilkan dengan menekan menu fitur. 


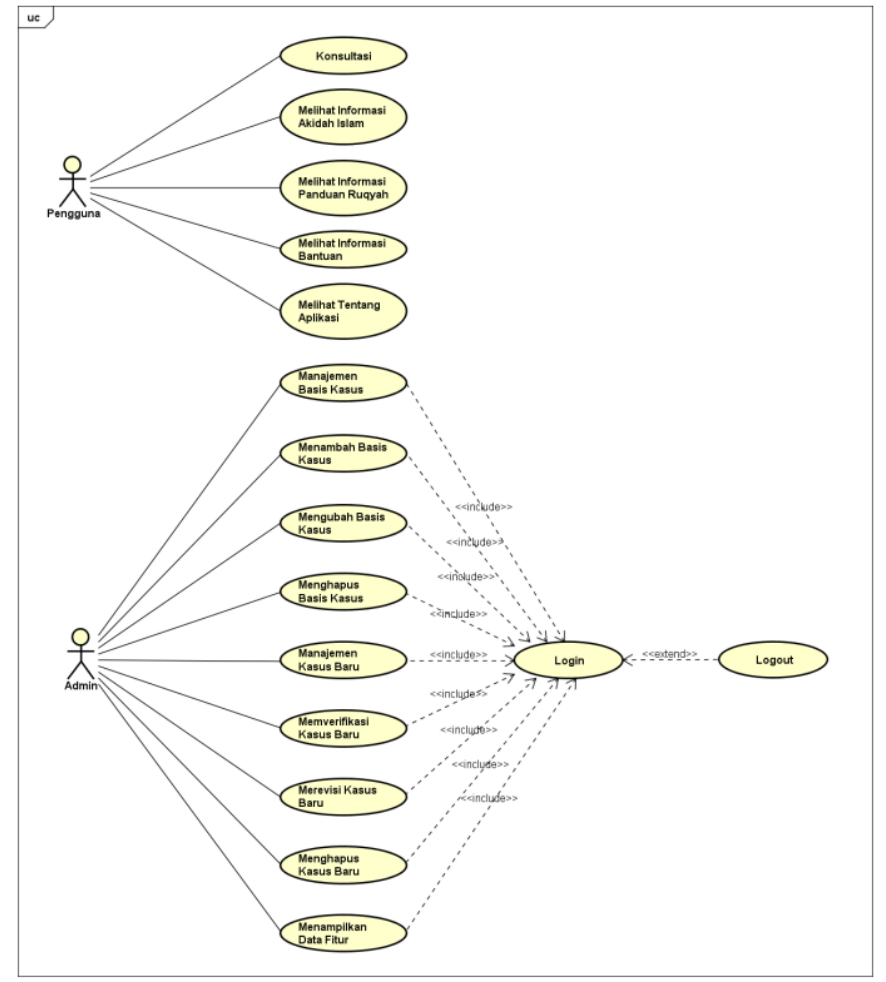

Gambar 3. Use case diagram sistem penentuan titik indikasi gangguan jin pada tubuh manusia.

\section{Pengujian Sistem}

Pengujian sistem dilakukan dengan metode blackbox yaitu validasi sistem. Terdapat 2 macam pengujian validasi sistem yang dilakukan.

a) Pengujian membandingkan hasil diagnosis pakar dengan hasil diagnosis sistem

b) Pengujian tahapan Case Based Reasoning (CBR)

\section{E. Hasil Perancangan Sistem}

Sistem yang dibangun adalah sistem penentuan titik indikasi gangguan jin pada saat ruqyah. Pada penelitian ini kasus dibatasi pada kasus kepala. Sistem akan mendiagnosis titik indikasi gangguan jin di tubuh manusia dan memberikan keluaran hasil titik indikasi berdasarkan gejala yang dirasakan. Tampilan aplikasi dapat dilihat pada Gambar 4, 5, dan 6.

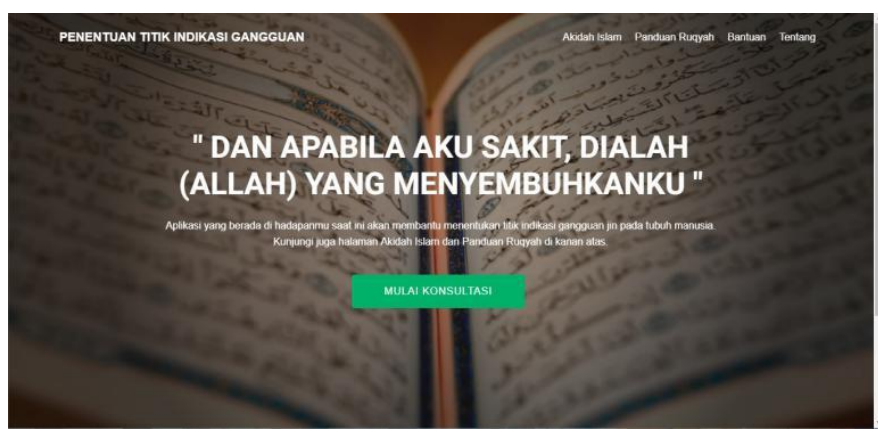

Gambar 4. Tampilan halaman utama pengunjung.

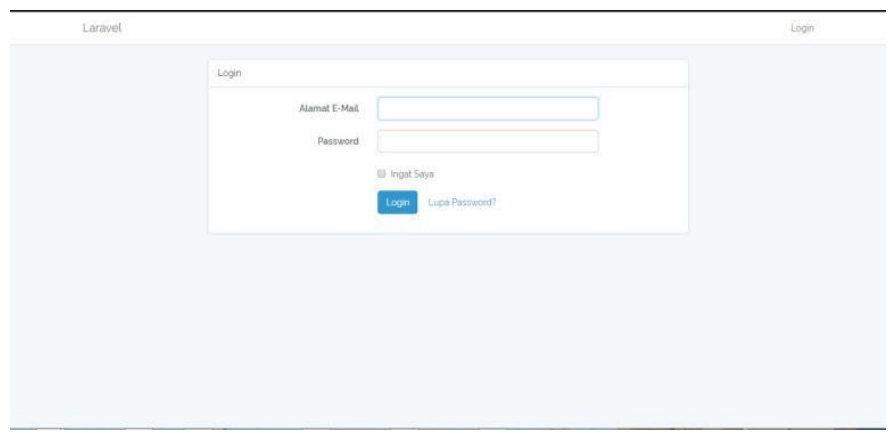

Gambar 5. Tampilan halaman login admin.

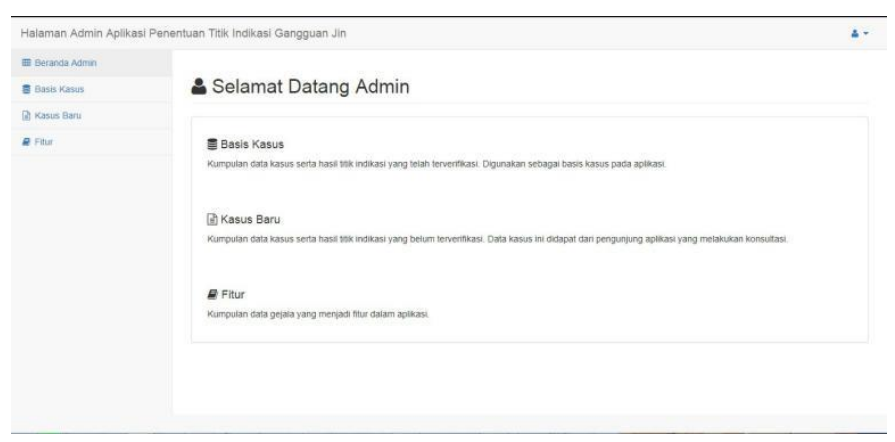

Gambar 6. Tampilan halaman utama admin.

\section{F. Hasil Pengujian}

a) Pengujian Membandingkan Hasil Diagnosis Pakar dengan Hasil Diagnosis Sistem.

Pada pengujian ini dilakukan dengan cara membandingkan hasil diagnosis kasus baru yang dilakukan oleh sistem dengan hasil diagnosis oleh pakar (praktisi ruqyah). Hasil pengujian dengan membandingkan hasil diagnosis oleh pakar dengan hasil diagnosis oleh sistem dapat dilihat pada Tabel 1 berikut.

Korespondensi : Wahyu Trihadi Saputra 
Tabel 3.

Hasil pengujian perbandingan hasil pakar dan hasil sistem

\begin{tabular}{|c|c|c|c|c|}
\hline Kasus & Gejala & Hasil Pakar & $\begin{array}{c}\text { Hasil } \\
\text { Sistem }\end{array}$ & $\begin{array}{c}\text { Kesesuaian } \\
\text { Hasil }\end{array}$ \\
\hline 1 & F009, F006, P005 & KM & KP, KM & TS \\
\hline 2 & F004 & KP & KP, MW & TS \\
\hline 3 & P001, P002 & MW & MW, HD & S \\
\hline 4 & F007, P004 & MW & KP, MW & TS \\
\hline 5 & F005, F010 & KM & KM, MW & TS \\
\hline 6 & F005, F009, P005 & KP & KP, MT & TS \\
\hline 7 & F011, P006 & KM, KP & KM, KP & S \\
\hline 8 & F012, F015 & MW & MW & S \\
\hline 9 & F013, F014 & KM & KM, MW & TS \\
\hline 10 & F017, F019 & HD & HD & S \\
\hline$\ldots$ & & $\ldots$ & $\ldots$ & $\ldots$ \\
\hline 65 & F016, F019, P005 & HD, KM & HD, KM & S \\
\hline
\end{tabular}

Keterangan:

$\mathrm{TS}=$ Tidak Sesuai $\mathrm{S}=$ Sesuai

\section{b) Pengujian Tahapan Case Based Reasoning (CBR).}

1) Pengujian tahapan retrieve dilakukan dengan menelusuri dan mendapatkan kasus-kasus dalam basis kasus yang mirip dengan kasus baru. Berikut proses dalam tahapan retrieve. Proses input data dan melakukan diagnosis titik indikasi gangguan dapat dilihat pada Gambar 7 dan 8.

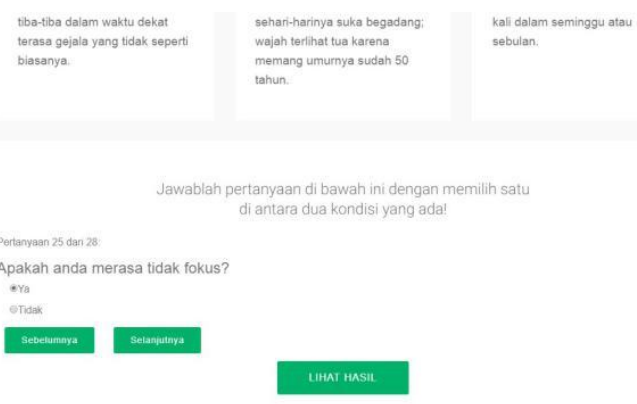

Gambar 7. Proses menjawab pertanyaan di halaman konsultasi.

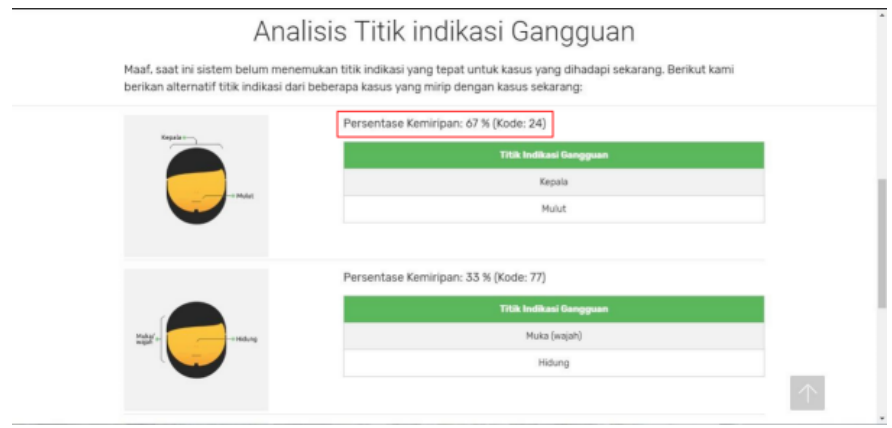

Gambar 8. Hasil konsultasi pada halaman hasil.
2) Pengujian tahapan reuse. Pengujian ini dilakukan dengan memproses penggunaan hasil titik indikasi dari kasus-kasus yang ada pada basis kasus untuk mengetahui titik indikasi pada kasus baru. Tahapan ini memberikan output berupa titik indikasi gangguan dari perhitungan similaritas menggunakan metode braun-blanquet. Hasil titik indikasi yang digunakan adalah dari kasus yang berada di basis kasus (kasus lama) yang kemiripannya paling relevan dengan kasus baru.

Hasil titik indikasi kasus lama yang memiliki kemiripan tertinggi dengan kasus baru menjadi alternatif hasil titik indikasi kasus baru dapat dilihat pada pada Gambar 9.

\section{Analisis Titik indikasi Gangguan}

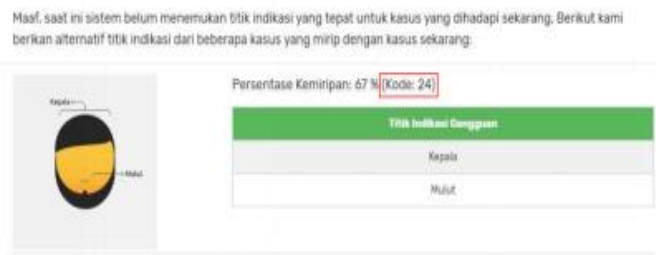

Gambar 9. Kasus lama yang digunakan sebagai hasil titik indikasi untuk kasus baru.

3) Pengujian tahapan revise. Pengujian ini dilakukan dengan meninjau kembali untuk perbaikan data hasil titik indikasi. Kasus yang ada ditinjau kembali gejala dan hasil titik indikasinya. Hasil akan disesuaikan dengan gejala yang dirasakan. Tahapan revise kasus baru dapat dilihat pada Gambar 10.

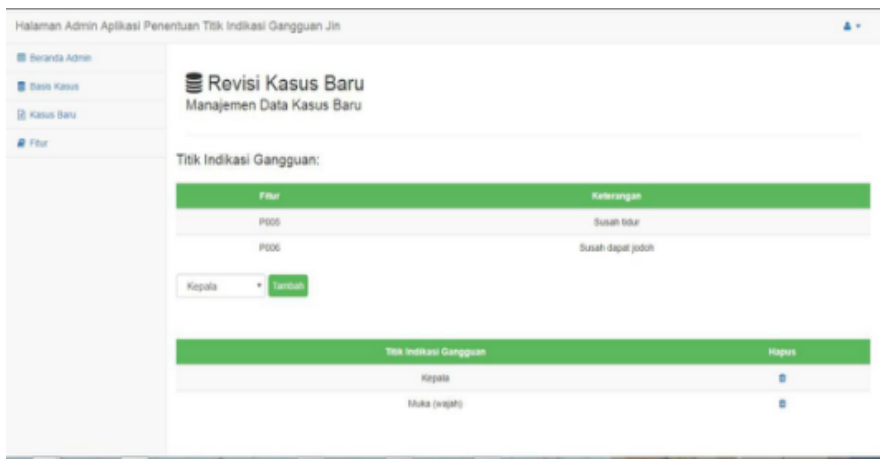

Gambar 10. Revisi kasus baru

4) Pengujian tahapan retain. Pengujian ini dilakukan dengan memindahkan data kasus baru ke basis kasus. Kasus baru ini telah melewati tahap verifikasi admin sehingga hasil titik indikasi kasus baru tersebut dapat menjadi solusi untuk kasuskasus selanjutnya. Tahapan retain dapat dilihat pada pada Gambar 11 dan 12. 


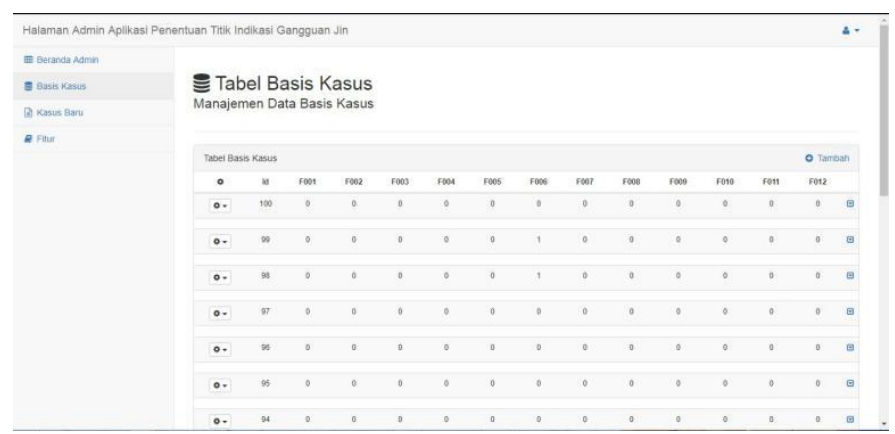

Gambar 11. Kondisi tabel basis kasus sebelum penambahan kasus

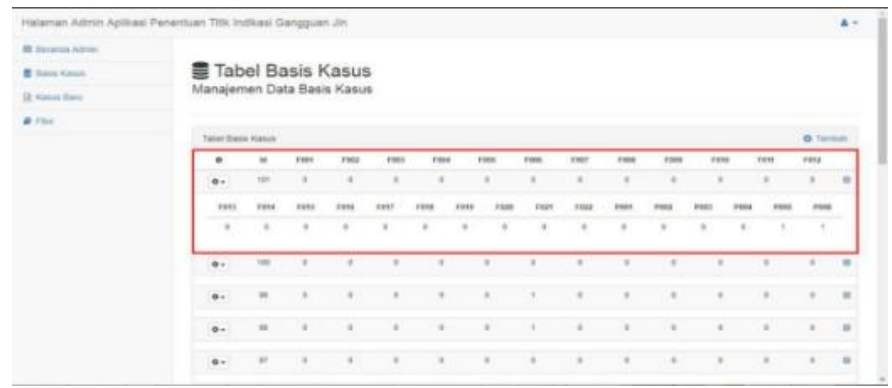

Gambar 12. Kondisi tabel basis kasus setelah penambahan kasus.

Hasil pengujian perhitungan similaritas menggunakan metode braun-blanquet dapat dilihat pada Tabel 2 berikut.

Tabel 4.

Hasil pengujian metode braun-blanquet

\begin{tabular}{|c|c|c|}
\hline Kasus & Similaritas & Kasus Mirip \\
\hline 1 & $(0,67),(0,67),(0,50)$ & $93,62,87$ \\
\hline 2 & $(0,50),(0.50),(0,33)$ & $52,56,21$ \\
\hline 3 & 1 & 4 \\
\hline 4 & $(0,50),(0,50),(0,50)$ & $16,27,48$ \\
\hline 5 & $(0,50),(0,50),(0,50)$ & $30,70,65$ \\
\hline 6 & $(0,67),(0,67),(0,50)$ & $92,24,57$ \\
\hline 7 & 1 & 39 \\
\hline 8 & 1 & 22 \\
\hline 9 & $(0,67),(0,67),(0,50)$ & $76,3,46$ \\
\hline 10 & 1 & 85 \\
\hline$\ldots$ & $\ldots$ & \\
\hline 65 & 1 & 82 \\
\hline
\end{tabular}

Pada Tabel 4 terdapat kolom similaritas yang berisi nilai dari similaritas yang dihasilkan sistem. Nilai 1 berarti gejala dari kasus baru memiliki kesamaan sempurna dengan gejala yang terdapat pada basis kasus. Maka sistem memberikan titik indikasi yang serupa dengan kasus lama (basis kasus) sebagai solusi permasalahan pada kasus baru. Nilai selain 1 pada kolom similaritas merupakan persentase kemiripan tertinggi gejala kasus baru atas basis kasus. Sistem memberikan 3 nilai similaritas tertinggi yang paling mendekati angka 1. Tiap nilai similaritas juga tertera nomor basis kasusnya pada kolom kasus mirip. Hal ini bersifat rekomendasi bagi pengguna untuk menggunakan hasil tersebut. Data kasus baru tersebut juga dapat direvisi dan dimasukkan ke dalam basis kasus oleh admin jika diperlukan.

\section{G. Analisis Hasil Pengujian}

Analisis hasil pengujian aplikasi penentuan titik indikasi gangguan jin pada tubuh manusia untuk ruqyah dapat disimpulkan sebagai berikut.

a) Hasil pengujian dengan mer sandingkan hasil pakar dan hasil sistem dari 65 kasus yang diuji (Tabel 4.3), didapatkan hasil terdapat 12 kasus yang menunjukkan hasil tidak sesuai yaitu pada kasus uji nomor 1, 2, 4, 5, 6, 9, 13, 37, 48, 49, 53, dan 58. Sehingga kasus yang sesuai sejumlah 53 kasus. Berdasarkan hasil pengujian ini, persentase kinerja sistem diukur dengan $\frac{53}{65} \times 100 \%=81,54 \%$

b) Hasil pengujian tahapan proses case based reasoning menunjukkan bahwa sistem ini dapat melakukan tahapan retrieve (menelusuri dan mendapatkan kasus-kasus dalam basis kasus yang mirip dengan kasus baru), reuse (menggunakan hasil titik indikasi dari kasus-kasus yang ada untuk mengetahui titik indikasi pada kasus yang baru), revise (merubah dan menyesuaikan output yang ditawarkan jika diperlukan), dan retain (proses penyimpanan data kasus baru ke basis kasus).

c) Hasil pengujian metode braun-blanquet menunjukkan bahwa berdasarkan hasil perhitungan similaritas sistem dari 65 kasus yang diuji (Tabel 4.4) terdapat 12 kasus kasus uji yang memiliki nilai similaritas kurang dari 1. Dengan rincian sebagai berikut.

(1) 4 kasus pada kasus uji nomor 1, 6, 9, dan 48 memiliki nilai similaritas 0.67

(2) 8 kasus pada kasus uji nomor 2, 4, 5, 13, 37, 49, 53, dan 58 memiliki nilaisimilaritas 0.5 .

12 kasus uji yang similaritasnya kurang dari 1 terjadi karena data kasus uji yang dimasukkan sebagai pengujian belum memiliki kasus yang sama dengan kasus yang telah ada di basis kasus. Tingkat similaritas dengan hasil sama dengan 1 dapat semakin tinggi dengan bertambah banyaknya basis kasus yang dimiliki sistem.

\section{KESIMPULAN/RINGKASAN}

Berdasarkan hasil analisis dan pengujian terhadap sistem penentuan titik indikasi gangguan jin untuk ruqyah, dapat disimpulkan bahwa sistem yang dibuat dapat melakukan

Korespondensi : Wahyu Trihadi Saputra 
proses 4R pada Case Based Reasoning (CBR). Tahapan retrieve (menelusuri dan mendapatkan kasus-kasus dalam basis kasus yang mirip dengan kasus baru), reuse (menggunakan hasil titik indikasi dari kasus-kasus yang ada untuk mengetahui titik indikasi pada kasus yang baru), revise (merubah dan menyesuaikan output yang ditawarkan jika diperlukan), dan retain (proses penyimpanan data kasus baru ke basis kasus). Sistem case based reasoning dengan perhitungan similaritas menggunakan metode braun-blanquet yang dibangun pada aplikasi dapat menentukan titik indikasi gangguan jin untuk ruqyah. Berdasarkan hasil pengujian metode braun-blanquet terhadap 65 kasus, terdapat 53 kasus yang memiliki nilai similaritas sama dengan 1. Berdasarkan hasil pengujian 65 kasus membandingkan hasil diagnosis pakar dengan hasil diagnosis sistem, 53 kasus memiliki kesesuaian hasil. Sehingga persentase keberhasilan sistem sebesar $81,54 \%$

\section{DAFTAR PUSTAKA}

[1] Tim Darul Haq. 2016. Panduan Praktis Ruqyah Sesuai dengan al-Quran \& as-Sunnah. Jakarta: Darul Haq

[2] Al Mubarak, Husain \& Bukhari Abdul Muid. 2015. Sembuh dengan Ruqyah. Depok: Hilal Media

[3] Tursina, 2012. Case-Based Reasoning untuk Diagnosa Penyakit Respirologi Anak Menggunakan Similaritas Simple Matching Coefficient.

[4] JMC, Jimmy. 2015. https://www.jmc.co.id/blog/detail/Saatnya- UntukMemilih-Desktop-Based-atau-Web-Based-Pada-Sistem-Berskala-Besar

[5] Luthfi, Emha Taufiq. 2010. Penerapan Case Based Reasoning Dalam Mendukung Penyelesaian Kasus. Yogyakarta

[6] Sukamto, Rosa Ariani dan M. Shalahudin. 2013. Rekayasa Perangkat Lunak Terstruktur dan Berorientasi Objek. Bandung: Informatika.

[7] Annisa. 2017. Diagnosis Kerusakan Komputer Menggunakan Metode Similarity Jaccard Coefficient. Jurnal Sistem dan Teknologi Informasi (JustIN) Vol. 1, No. 2, 2017.

[8] Tursina. 2016. Prediksi Proses Persalinan Menggunakan Case Based Reasoning. Jurnal Edukasi dan Penelitian Informatika (JEPIN) Vol. 2, No. 1, 2016.

Korespondensi : Wahyu Trihadi Saputra 